\title{
Cardiac Progenitor Cells and their Therapeutic Application for Cardiac Repair
}

\author{
Lukas Cyganek ${ }^{1,2}$, Simin Chen ${ }^{1,2}$, Thomas Borchert ${ }^{1,2}$ and Kaomei Guan ${ }^{1,2 *}$ \\ ${ }^{1}$ Department of Cardiology and Pneumology, University Medical Center Gottingen, Robert-Koch-Str. 40, 37075 Gottingen, Germany \\ ${ }^{2}$ DZHK (German Center for Cardiovascular Research), Partner site Gottingen, Germany
}

\begin{abstract}
Heart disease is the principal cause of death in humans. Stem cell-based therapy for heart regeneration has long been seen as a potential application since the heart lacks adequate intrinsic regenerative potential. In the cardiovascular field, clinical trials have already been carried out by implantation of both bone marrow-derived stem cells and cardiac resident progenitor cells derived from the adult heart tissue into the injured myocardium to restore the functionality of the heart after damage. However, before a robust stem and progenitor cell-based therapy for cardiovascular diseases can be applied in the clinical setting, more research is necessary to generate sufficient quantities of functional cardiomyocytes from stem cells and to understand behavior of cardiomyocytes upon transplantation. A comprehensive understanding of the developmental processes involved in cardiogenesis might support further investigations in more efficient cell-based regeneration therapies. This review discusses the molecular aspects of cardiogenesis during early development and links the insights with the in vitro generation of cardiac progenitor cells as well as functional cardiomyocytes. Furthermore, we discuss the advantages of cardiac progenitor cells and cardiomyocytes derived from pluripotent stem cells, cardiac resident stem cells in regenerative applications to cope with the damaged heart.
\end{abstract}

Keywords: Cardiac progenitor cells; Cardiomyocytes; Molecular mechanism; Cardiac resident stem cells; Heart regeneration

\section{Introduction}

Cardiovascular diseases are considered to be one of the largest health problems in developed countries by being the principal cause of death in humans with over 4 million deaths per year in Europe alone (http://www.escardio.org/about/what/advocacy/EuroHeart/ Pages/2012-CVD-statistics.aspx). Furthermore, congenital heart disease as the most common birth defect in humans affects nearly $1 \%$ of newborns. With inclusion of spontaneous abortions, the incidence is exaggerated to $10 \%[1]$.

During early embryogenesis, the heart is the first functional organ that pumps blood to provide the growing organism with required metabolic demands like essential nutrients and oxygen. The development of the heart comprises complex processes of cell migration, proliferation, differentiation, specification and maturation throughout cardiogenesis. Although a persistent heart function is fundamental for development and survival of the organism, the heart lacks efficient, intrinsic regenerative potential to restore the functionality after cardiac damage. Previous studies show that the mitotic renewal rate in the human myocardium is very low and most cardiomyocytes will never be exchanged during a normal life span [2]. Experimental evidence suggests that the heart harbors a resident population of stem cells which are able to give rise to cardiomyocytes, smooth muscle and endothelial cells $[3,4]$. However, these populations have limited capacity to replace a large number of cardiomyocytes lost after a serious heart attack [5]. Therefore, a robust novel therapy to regenerate lost myocardium could help millions of patients every year.The limited regeneration capability of heart tissue has prompted methodological developments for creating de novo cardiomyocytes, both in vitro and in vivo. Newly generated cells are required to integrate electrically and mechanically in order to enhance the deficient pumping function of the heart.

The stem cell-based cellular therapy focusing on the possibility of re-growing heart muscle has been regarded as an innovative option in therapeutic approaches in the recent years [6,7]. Significant progress has already been made in this field [8,9]. Patient-specific induced pluripotent stem cells (iPSCs) may be a realistic cell type for providing a source of new functional cardiomyocytes [10]. Their therapeutic applications may circumvent the ethical concerns and immunogenic complications associated with human embryonic stem cells (ESCs). However, before the application of iPSCs in regenerative medicine, many aspects have to be addressed: for example, generation of sufficient quantities of functional cardiomyocytes, prevention of the massive amount of cell death after transplantation, induction of cardiomyocyte maturation derived from such pluripotent stem cells, and demonstration of safety and efficacy in animal models and preclinical trials.

During early cardiogenesis, the cardiac identity of the progenitor cells is regulated by tightly coordinated, spatially and temporally active signaling pathways and molecular mechanisms leading to the progressive restriction of undifferentiated progenitors to the different cardiovascular lineages. Dissecting the molecular basis of cardiac progenitor cell emergence, proliferation, diversification, specification, phenotypic modulation and subsequent maturation does not only help to understand the developmental processes of embryonic cardiogenesis and cardiovascular diseases but also facilitates investigations in stem cell-based regeneration therapies of the failing heart. A comprehensive knowledge would allow developing more extensive strategies in cardiomyocytes differentiation and their structural and functional

*Corresponding author: Kaomei Guan, PhD, Department of Cardiology and Pneumology, University Medical Center Göttingen, Robert-Koch-Str. 40, 37075 Gottingen, Germany, Tel: 0049-(0)551-395321; Fax: 0049-(0)551-398124 E-mail:kguan@med.uni-goettingen.de

Received April 15, 2013; Accepted June 03, 2013; Published June 07, 2013

Citation: Cyganek L, Chen S, Borchert T, Guan K (2013) Cardiac Progenitor Cells and their Therapeutic Application for Cardiac Repair. J Clin Exp Cardiolog S11: 008. doi:10.4172/2155-9880.S11-008

Copyright: (C) 2013 Cyganek L, et al. This is an open-access article distributed under the terms of the Creative Commons Attribution License, which permits unrestricted use, distribution, and reproduction in any medium, provided the original author and source are credited. 
maturation, which could provide the basis for the establishment of efficient therapeutic approaches in heart failure and disease modeling.

This review aims at highlighting the current knowledge of the developmental processes in cardiogenesis at molecular levels with special focus on the emergence and early differentiation of cardiac progenitor cells (CPCs). We emphasize the potential of CPCs and cardiomyocytes in regenerative approaches, pointing out recent advances in regenerative cell-based applications and therapies for cardiovascular diseases. Furthermore, we attempt to shed light on the discovery of cardiac resident stem cells in the adult heart and their potential in cardiac repair.

\section{Cardiac Progenitor Cells: From the Developmental Prospective}

The mammalian heart is comprised of a highly diversified set of both muscle and non-muscle cell types, including chamber-specific cardiomyocytes, pacemaker cells, the cardiac conduction system, endothelial cells, vascular smooth muscles, and endocardial cells [11]. These various cardiovascular cell lineages are formed from a closely related set of multipotent cardiac progenitor cells (CPCs) in the early embryonic heart $[12,13]$.

\section{The heart development and origin of CPCs}

In vertebrates, the development of the heart is initiated during gastrulation by induction of the mesodermal cells located in the anterior lateral part of the primitive streak $[14,15]$. The early embryonic heart field can be divided into the primary or first heart field (FHF) and secondary heart field (SHF). The cardiac mesodermal cells from the posterior levels of the cardiac region of the primitive streak migrate cranially under the head folds of the embryo and form the FHF, also referred to as the cardiac crescent. The SHF, also known as the anterior heart field, lies medially and anteriorly to the FHF $[14,16]$.

The FHF becomes the exclusive source of the left ventricular myocardium and partially contributes to the atrial myocardium, whereas the SHF contributes primarily to the right ventricular myocardium and the outflow tract $[17,18]$. However, it is believed that both of the myocardial progenitor lineages with distinct molecular signatures are derived from a common precursor population which segregates early at the onset of gastrulation [11,12,19-21]. In more advanced stages of cardiac development, the FHF-derived CPCs rapidly expand in size and fuse at the ventral midline to form the bilaterally symmetric primitive heart tube consisting of an inner layer of endocardial cells and an outer layer of myocardial cells, which becomes functional at day 21 in humans and begins to pump blood around the embryo [22-24]. As the first asymmetric event in development, the heart tube undergoes rightward looping by the anterior movement of the venous pole and the realignment of the future ventricles and atria $[16,25]$. The SHF located dorsally in the heart tube rearranges posteriorly and anteriorly upon looping, and the SHF-derived CPCs at the arterial and venous poles subsequently contribute to heart tube elongation and expansion $[14,26,27]$. Furthermore, cells from additional sources like the pharyngeal arches, the proepicardium or neural crest cell derivatives with neuroectodermal origin cooperate in the formation of the heart $[18,28]$. The four chambered heart develops by expansion, remodeling, subsequent septation and valve formation of the cardiac tissue which terminally differentiates and matures anatomically and functionally (week 4-10 in humans) [22,29,30].

\section{Signaling pathways involved in formation and differentiation of early mesoderm into CPCs}

A series of signaling mechanisms including members of the bone morphogenetic protein (BMP), nodal, activin, transforming growth factor- $\beta$ (TGF- $\beta$ ), sonic hedgehog (Shh), fibroblast growth factor (FGF), Wnt, and notch proteins co-operate in complex positive and negative networks to induce cardiogenesis (Figure 1A) [14,25,31].

The initial formation of the early mesoderm during gastrulation is induced by canonical $\mathrm{Wnt} / \beta$-catenin signaling in the posterior epiblast by driving expression of the mesendodermal markers Brachyury and Eomesoderminfollowedbyup-regulation ofgenesinvolved in mesoderm patterning and epithelial-mesenchymal transition [31,32]. Brachyury and Eomesodermin prompt the expression of mesoderm posterior 1 (Mesp1) as one of the key regulators to induce the differentiation of early mesodermal cells into CPCs $[33,34]$. Consequently, the formation of the cardiac mesoderm is initiated, which further gives rise to the FHF, SHF, endocardium and proepicardium [18]. Since canonical $\mathrm{Wnt} / \beta$-catenin signaling inhibits the cardiac lineage, the pathway is rapidly silenced in the prospective cardiogenic mesoderm by Wnt antagonists from adjacent tissues [35-37]. Secreted factors including BMP2/4, FGF2/4/8, Shh, non-canonical Wnts (Wnt5a, Wnt11) and canonical Wnt inhibitors (Dickkopf-1 homolog, Dkk1), which are released by the underlying anterior endoderm, promote the cardiac phenotype [38-45]. These signals together with cardiac inhibitors like canonical Wnts (Wnt3a/8) and BMP inhibitors (noggin, chordin) produced by the neural ectoderm and the notochord, respectively, play important roles in specification, maintenance and shaping of the cardiac precursor zone, a region characterized by high BMP and low Wnt activity (Figure 1A) [36,46-48].

\section{Transcriptional regulation in formation and differentiation of CPCs}

The transiently expressed Mesp1 together with Mesp2 are the earliest molecular markers of CPCs and key regulators of the cardiovascular cell fate. They are required for the primitive streak delamination and label all cardiac cells of mesodermal origin [49-51]. In the presence of the canonical Wnt inhibitor Dkk1 Mesp1 directly down-regulates pluripotency and early mesodermal genes as well as up-regulates the cardiac markers NK2 transcription factor related locus 5 (Nkx2-5), GATA4 and Islet Lim homeobox 1 (Isl1) [33,52,53].

$\mathrm{Nkx} 2-5$ as one of the first genes expressed in the early vertebrate embryo is crucial in the induction of cardiogenesis by directly and indirectly activating further transcriptional factors like GATA4, myocyte enhancer factor 2C (MEF2C), T-box 5 (Tbx5) or heart and neural crest derivatives expressed transcript 1 (Hand1) [54,55]. Upon induction of the cardiogenic program in the CPCs at primitive streak stage, a complex network of co-operating developmental key transcription factors, such as Nkx2-5, GATA4/5/6, MEF2C, Tbx $5 / 20$, Hand $1 / 2$ and their downstream targets subsequently establishes the cardiac phenotype $[16,18]$.

The GATA-binding transcription factor GATA4 is involved in multiple steps of differentiation and morphogenesis in the developing heart [56-60]. GATA4 together with the chromatin remodeling component Baf60c has been shown to directly induce Nkx2-5 gene expression in mesodermal cells, where the expression of both GATA4 and Nkx2-5 is maintained in a positive feedback loop [61-63]. Furthermore, GATA4 associates in a complex with Nkx2-5 and Tbx5 to activate downstream cardiac genes [64-67]. In the progressive heart development Nkx2-5 is important in cardiac looping and in ventricular 
marker expressionand its mutations give rise to congenital heart disease in humans $[68,69]$. The transcription factor MEF2C plays a critical role in the determination and differentiation of the procardiogenic mesoderm and in cardiac looping [30,70,71]. Additionally, disrupted MEF2C function results in down-regulation of Hand1/2 and failing to properly develop to a right ventricle [72]. In humans, MEF2C mutants display non-syndronic congenital heart defects [73]. Tbx5 has been implicated in multiple processes throughout different stages of cardiogenesis including heart tube formation, cardiac looping and chamber septation accompanied by spatial and temporal expression changes in the CPC subpopulations [74-78]. Hand1 and Hand2 are expressed in the early cardiac development with significant roles in differentiation, rightward looping and normal ventricular development [79-82]. During the cardiac crescent stage the expression of the transcription factors in the early CPCs progressively changes with Hand 1 being restricted to the FHF and later left ventricle, whereas Hand 2 is confined in the SHF which further forms the right ventricular myocardium and the outflow tract $[83,84]$.
Soon after cardiac induction, the CPC population segregates into two different lineages: the FHF maintains expression of markers like Nkx2-5, Tbx 5 and Hand1, whereas the SHF is defined by Isl1-, Hand2and FGF10-positive cells [22]. Isl1 has been regarded as a specific marker for the SHF [85]. Recent advances in dissecting the molecular mechanisms of cardiogenesis revealed that Isl1 is additionally expressed in the FHF and its derivatives [86-88]. However, Isl1 mutants do not display any defects in primitive heart tube formation, but have deficits in migration, proliferation and survival of SHF-derived CPCs $[85,87,89]$. Isl1 can be activated by canonical $\mathrm{Wnt} / \beta$-catenin signaling [90] and is considered to be a key regulator of the SHF by directly and indirectly interacting with further transcription factors in a complex regulatory network including MEF2C, Nkx2-5, GATA, Fork head box (Fox) transcription factors, Tbx1/20 and FGF8/10. Therefore, it is crucial for the development of the right ventricle and the outflow tract [13,91-93] Tbx1, which is activated by the Fox transcription factors, was shown to have a high impact in promoting the proliferation of SHF-derived CPCs with consequent impact on outflow tract myocardium expansion

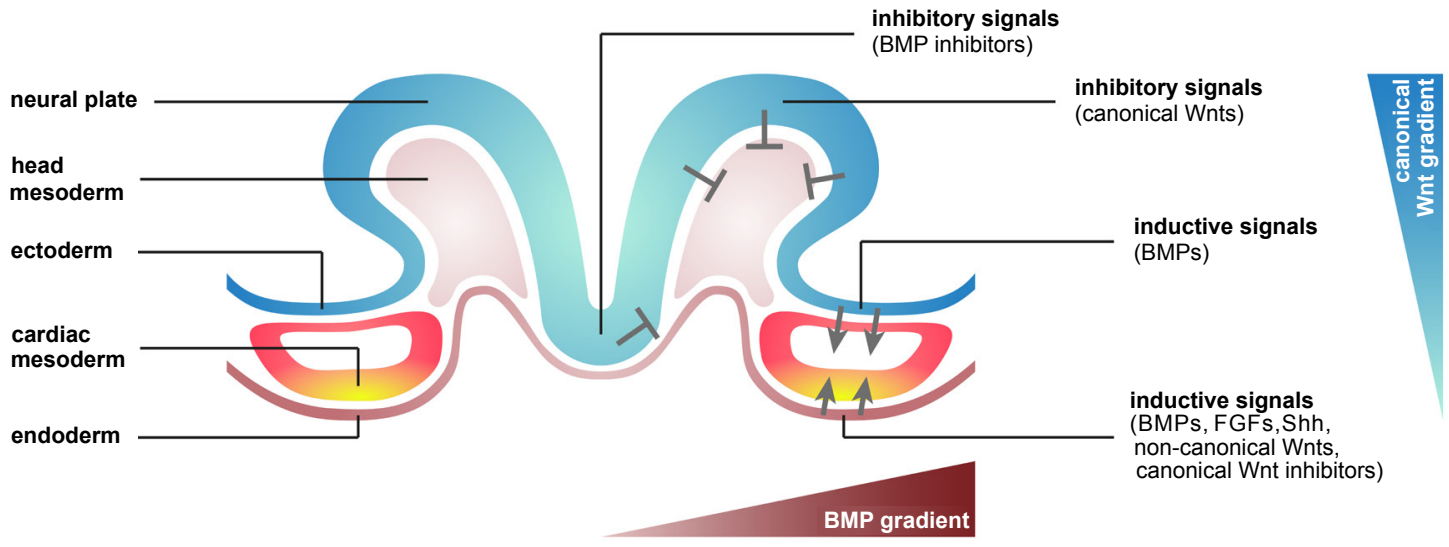

B in vitro

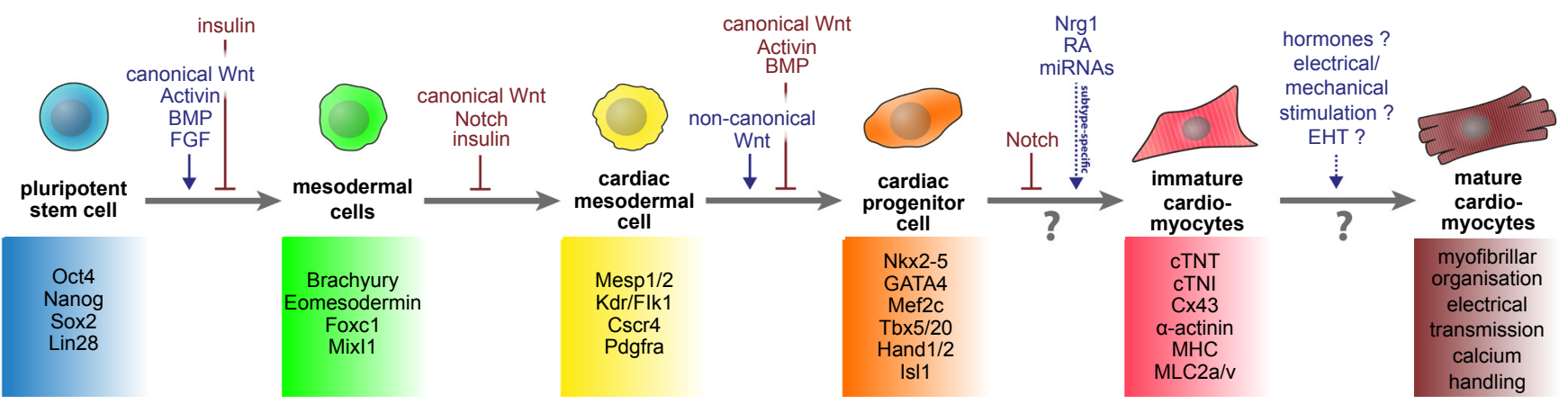

Figure 1: In vivo and in vitro cardiogenesis. (A) Schematic illustration of a transverse section of an early stage mammalian embryo showing counteracting signals which shape the cardiac precursor zone in vivo. Cardiogenic secreted factors for cardiac mesoderm formation are emitted by the underlying anterior endoderm and by the anterior ectoderm including bone morphogenetic proteins (BMPs), fibroblast growth factors (FGFs) sonic hedgehog (Shh), non-canonical Wnts and canonical Wnt inhibitors. These signals counteract with cardiac inhibitors like canonical Wnts and BMP inhibitors released by the neural plate. The cardiac mesoderm is defined by a region with high BMP and low Wnt activity. (B) Sequential steps in cardiac differentiation in vitro from pluripotent stem cells to functional cardiomyocytes. Positive (blue) and negative (red) acting signals influence cardiomyogenesis in vitro and display parallels to embryonic development. Early mesodermal cells are induced by canonical Wnt, activin, BMP and FGF signaling and inhibited by insulin. Diversification to cardiac mesodermal cells can be inhibited by canonical Wnts, notch and insulin signaling. Cardiac progenitor cell specification is promoted by non-canonical Wnts and negatively regulated by canonical Wnt, activin and BMP signaling. Notch signaling promotes cardiac progenitor cell differentiation and inhibits cardiomyocyte differentiation. Neurogenin 1 (Ngn1), retinoic acid (RA) and specific microRNAs (miRNAs) direct cardiomyocyte subtype-specific differentiation. Structural and functional maturation is not well understood. Maturation migh be provoked by hormones, electrical and mechanical stimulation and organization in 3D engineered heart tissues (EHTs). Typical markers and characteristics for the different cell types are indicated. 
[94-99]. Interestingly, both Isl1 ${ }^{+}$and $\mathrm{Tbx} 1^{+} \mathrm{CPCs}$ show the potential to differentiate into myocardial, endothelial and vascular smooth muscle cells [89,100-102]. Additionally, specific microRNAs like miR-1 were recently brought into focus of cardiogenesis [103].

Fine-tuned synergistic interactions between multiple signals encompassing the CPCs including canonical $\mathrm{Wnt} / \beta$-catenin, noncanonical Wnt, FGF, BMP and notch pathways have been implicated in CPC proliferation versus cardiomyocyte differentiation, although the complex mechanisms are not yet fully understood $[18,35,87,89,104-$ 109]. Furthermore, these various signaling networks and numerous additional transcription factors are implicated in morphogenesis of the four-chambered heart and in the terminal maturation of cardiomyocytes, namely the expression of structural proteins (such as troponin I, T or C, myosins and $\alpha$-actinin) and functional proteins (ion channels and gap junction proteins needed for electrical stimuli transmission, intracellular channels such as ryanodine receptor 2 responsible for calcium handling) for mechanoelectrical activity, calcium handling, myofibril organization or sarcomeric striations.

\section{Cardiac Progenitor Cells: Derived From Pluripotent Stem Cells}

Human pluripotent stem cells have been proven to constitute a promising source for a myriad of cell types. Diverse molecular insights into embryonic cardiogenesis have been transferred to stem cell biology by supporting the efficient generation of cardiomyocytes in vitro. Influencing important signaling cascades and molecular mechanisms throughout the differentiation of pluripotent stem cells under culture conditions can guide the cellular phenotype into a defined direction (Figure 1B). In recent years numerous protocols have been developed to produce cardiomyocytes from ESCs and iPSCs, which become increasingly sophisticated.

The initial strategy to obtain cardiomyocytes in vitro was the differentiation in embryoid bodies, in which stem cell clusters differentiate spontaneously into cells from all three germ layers including diverse multipotent cardiovascular cell lineages [110,111]. However, this spontaneous differentiation method yielded in very low amounts of cardiomyocytes. A first step toward targeted differentiation was the differentiation of human pluripotent stem cells on visceral endoderm-like cells which could artificially mimic the in vivo situation by providing the differentiating pluripotent cells with requisite signals for the cardiac phenotype [112]. The yield of cardiomyocytes via this method was increased by addition of cyclosporine A [113], addition of ascorbic acid and use of serum-free approaches [114].

Recently established protocols to control and direct differentiation of pluripotent stem cells into cardiomyocytes utilize our understanding of molecular mechanisms regulating early cardiogenesis. Induction of mesendodermal and cardiac mesodermal identities has been proven to be critical in the generation of cardiovascular cells from pluripotent stem cells. During in vitro differentiation of pluripotent stem cells, similar to in vivo, Brachyury induces the expression of Mesp1 [115] and Tbx5 associates with $\mathrm{Nkx} 2-5$ and synergistically promotes cardiomyocyte differentiation [116]. In addition, Nkx2-5 expressing CPCs or Isl $1^{+}$and $\mathrm{Tbx}^{+} \mathrm{CPCs}$ derived from pluripotent stem cells show the potential to differentiate into myocardial, endothelial and vascular smooth muscle cells $[12,86,89,101]$.

Many groups focused their research in manipulating the signaling pathways identified in in vivo studies, and applied this in the in vitro differentiation system of pluripotent stem cells, including BMP, activin,
FGF, canonical Wnt/ $\beta$-catenin and notch signaling. Addition of BMP4 [117], BMP4 and activin A [118,119], BMP4 and FGF2 [120], activin A and FGF2 [121], canonical Wnt3a [122] or a mixture including BMP4, activin A and FGF2 [123] over the first days of differentiation greatly enhanced the formation of mesendoderm and subsequently generated a large amount of cells which expressed various cardiomyocyte markers in both embryoid bodies and monolayer culture conditions (Figure 1B). Furthermore, it was shown that notch $[124,125]$ and insulin [126128] signaling possess strong inhibiting effects on cardiac mesoderm formation during the initial stages of cardiogenesis. Interestingly, the time point, at whichthe cells were passaged before differentiation, greatly influenced differentiation efficiency $[120,129]$.

Canonical Wnt/ $\beta$-catenin signaling displays a biphasic role in embryonic heart development by inducing mesodermal commitment and inhibiting cardiac mesoderm specification (Figure 1A). Treatment with Wnt inhibitors at later stages of cardiogenesis under in vitro culture conditions could boost the cardiac differentiation. Negative regulation of canonical $\mathrm{Wnt} / \beta$-catenin signaling after mesodermal diversification during in vitro differentiation of pluripotent stem cells by the Wnt antagonist Dkk1 [130,131] or the chemically produced inhibitors IWR-1, IWP-2, IWP-4 [129,132,133] enhanced the yield of cardiomyocytes up to $97 \%$. Recent studies further reveal that inactivation of BMP pathways by the BMP antagonist noggin [134] or small molecule inhibitors dorsomorphin or dorsomorphin homologue-1 [135] during the cardiac mesoderm formation stage of in vitro differentiation of human pluripotent stem cells can promote cardiac differentiation. Activated notch signaling can promote the proliferation of CPCs by blocking the subsequent differentiation steps [136-139]. On the other hand, induction of non-canonical Wnts in precardiogenic cells also results in higher CPC differentiation efficiency along with the typical expression of CPC markers, in both mouse and human pluripotent stem cells $[42,140,141]$. Treatment with factors like ascorbic acid results in expansion of the CPC population whereas induction of insulin-like growth factor (IGF) signaling influences the cardiomyocyte proliferation [142-145].

The current focus of research is the discovery of signals that play a role in later steps of cardiogenesis leading to the different subclasses of cardiomyocytes and their structural and mechanical maturation. The endogenous Neurogenin 1 ( Nrgl) signaling, which is a wellestablished regulator in later cardiogenesis in vivo, has been shown to be involved in regulating cardiac subtype specification during in vitro differentiation of human pluripotent stem cells [146]. When endogenous Nrg1 signaling was inhibited, there was a substantial increase in the proportion of cardiomyocytes exhibiting the nodal phenotype [146]. In contrast, retinoic acid inhibits CPC differentiation into ventricular cardiomyocytes and promotes atrial phenotypes instead [147]. Further critical factors of in vivo heart morphogenesis and differentiation might also have an impact in in vitro differentiation and could provide new insights regarding more detailed strategies towards distinct cardiac subtypes. Additionally, microRNAs like miR1 and miR-499 are considered to be a relevant compound in directed cardiogenic differentiation and maturation $[148,149]$.

The in vitro generated cardiomyocytes possess an immature phenotype compared to adult cardiomyocytes [111,150]. Therefore, it is important to elucidate how maturation can be achieved under in vitro culture conditions. Recent studies reported that long-term culture protocols could enhance the cardiomyocyte maturation [151]. Mechanical stimulation facilitated by engineered heart tissues is expected to guide immature cardiomyocytes to more mature 
phenotypes under ex vivo pseudo-physiological conditions [152]. Additionally, a myocardium-derived hormone, named relaxin, could be a potential candidate for the terminal maturation of cardiac cells [153].

Numerous protocols have been described enabling the production of a large number of cardiomyocytes in high purities, thereby paving the way toward cardiac regeneration by cardiomyocyte transplantation. However, the complex mechanisms of terminal maturation are far from being fully understood. In the future, it will be interesting to decipher more precisely, which additional factors provoke the differentiation towards distinct subclasses of cardiomyocytes and prompt a maturation towards adult-like cardiomyocytes.

\section{Cardiac Resident Stem Cells in the Adult Heart}

Although the adult heart lacks adequate intrinsic potential to regenerate itself after damage, experimental evidences show that the adult heart harbors a population of cardiac resident stem cells which are able to give rise to cardiomyocytes, smooth muscle and endothelial cells [3,4]. Different pools of cardiac resident stem cells have been classified according to their expression profiles and surface markers, namely side population (SP) cells, c- $\mathrm{Kit}^{+}, \mathrm{Sca}-1^{+}, \mathrm{Isl}^{+}$, cardiospheres and cardiosphere-derived CPCs.

\section{Side population (SP) cells}

Side population (SP) cells, first isolated from the bone marrow [154], can be identified by their ability to exclude Hoechst 33342 dye due to expression of ATP-binding cassette transporters ABCG2 and MDR1 [155]. Martin et al. have first isolated them from embryonic and adult mouse hearts [156]. In rodents, cardiac SP cells were reported to be positive for stem cell antigen-1 $\left(\mathrm{Sca}^{+} 1^{+}\right)$and $\mathrm{CD} 34\left(\mathrm{CD} 34^{+}\right)$, negative for $\mathrm{c}-\mathrm{Kit}(\mathrm{c}-\mathrm{Kit})$, CD31 (CD31') and CD45 (CD45), as well as expressing cardiac specific transcription factors such as MEF2C, GATA4 and Nkx2-5, and have the potential to differentiate into cells expressing sarcomeric proteins troponin and cardiac $\alpha$-actinin $[157,158]$. Their self-renewal properties were also demonstrated by expression of cell cycle regulators such as notch and TGF- $\beta[156,159]$. A recent study demonstrates that the adult human heart contains a pool of SP cells expressing the breast cancer resistance protein (BRCP) (Figure 2) [160]. Human cardiac $\mathrm{BRCP}^{+}$cells exhibit cardiac differentiation potential in vitro [160], and, as with mouse cardiac SP cells, are negative for c-Kit. Interestingly, Sca- $1^{+} \mathrm{SP}$ cells in murine studies showed the highest potential of differentiating into cardiac lineages [158] in contrast to human cardiac $\mathrm{BCRP}^{+}$cells which are negative for Sca-1 [160]. Despite the in vivo potential of SP cells to be able to home to the injured heart and lead to an increase in neovascularization, cardiomyocyte regeneration, and improvement in cardiac function $[161,162]$, absolute proof of the source of SP cells and its bona fide stem population defined by clonogenicity and self-renewal have not yet been reported.

\section{c-Kit positive cells}

c-Kit is a tyrosine kinase receptor for the stem cell factor initially used to isolate haematopoetic stem cells from bone marrow [163]. The existence of c-Kit ${ }^{+}$cells in the adult heart was first described in 2003 by Beltrami and colleagues where they managed to isolate c-Kit ${ }^{+}$, Lin and CD45 cells from the adult rat heart with significant potential to differentiate into cardiomyogenic lineages and regenerate the infarcted myocardium [3]. c-Kit ${ }^{+}$cells express cardiac-specific transcription factors Nkx2-5, GATA4 and GATA5. The long-term culture of c-Kit ${ }^{+}$ cells has been established and exhibits self-renewal and clonogenic properties [164]. They have been proven to enhance therapeutic efficacy by pre-treatment with IGF1 and hepatocyte growth factor before injection into rodents with myocardial infarction [165]. Although $\mathrm{c}-\mathrm{Kit}^{+}$cells show an apparent therapeutic utility, it has been pointed out that these subpopulations of cardiac resident stem cells are rare within the adult human myocardium [160], and the cardiomyocyte derivatives are structurally immature and deficient in calcium handling. However, a recent study reported that human cardiac c-Kit ${ }^{+}$progenitor cells are readily expanded and enriched using a single-cell culture protocol with enzymatic digestion [166], providing a promising tool for isolation of c-Kit ${ }^{+}$derivatives for cellular therapy.

\section{Sca-1 positive cells}

Mouse Sca- 1 was first identified as a member of the Ly- 6 antigen family, and is widely used as a marker for enrichment for haematopoetic stem cells [167]. These cells express CD31 but were negative for c-Kit, CD45, CD34 and Flk1. When treated with oxytocin, Sca- $1^{+}$cells expressed genes encoding cardiac transcription factors and contractile proteins and showed sarcomeric structure with spontaneous beating [168]. In a study by Tateishi and co-workers, they demonstrated that cardiac stem cell proliferation and survival after direct cell-grafting into ischemic myocardium requires Sca-1 to up-regulate the secreted paracrine effectors that augment neoangiogenesis and limit cardiac apoptosis [169]. The importance of Sca- $1^{+}$cells in cardiovascular regeneration is further emphasized by Sca- 1 knockout studies in mouse models which demonstrate cardiac defects in myocardial contractility and repair consistent with impairment of cardiac resident stem cells proliferative capacity associated with altered canonical Wnt signaling [170]. Interestingly, although no Sca-1 homologue in humans have been identified, human Sca- $1^{+}$cells from the heart isolated with the rodent antibody were able to form functional cardiomyocytes upon stimulation with TGF- [171].

\section{Isl1 positive cells}

Isl1 is expressed during development by the SHF and contributes to the right ventricle and outflow tract. Isl $1^{+}$cells are found in the embryonic and postnatal mouse, rat and human heart [172]. Isl- $1^{+}$cells are a distinct population of cardiac resident progenitors in that they do
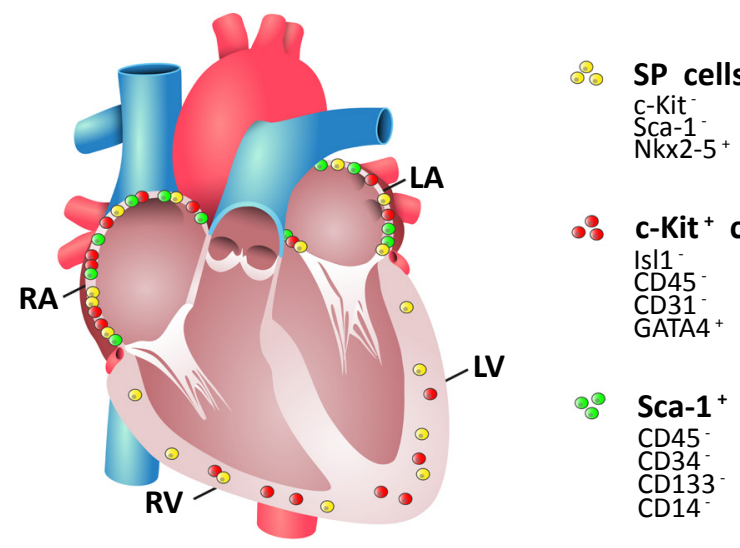

- C-Kit $^{+}$cells

Isl1.

CD45

GDTA4

Figure 2: Localization of cardiac resident progenitor cell populations in the human adult heart. Both side population (SP)- and c-Kit-positive cells can be found in the atrial and ventricular myocardium. In contrast, Sca1-positive progenitors are identified in the atria only. Characteristic markers for each resident population are indicated. LA, left atrium; LV, left ventricle; RA, right atrium. 
not exclude Hoechst 33342 dye and did not express c-Kit and Sca-1. It has been long regarded that Is $11^{+}$cells are limited in their therapeutic potential as the progenitor population declines rapidly after birth. However, the expansion of Isl1 $1^{+}$cardiac progenitors could be promoted by using directed $\mathrm{Wnt} / \beta$ catenin signaling via the regulation of FGF ligands [35].

\section{Cardiospheres and cardiosphere-derived cardiac progenitor cells}

There has been a recent focus on a subpopulation of undifferentiated, self-adherent cell clusters termed "cardiospheres" [173]. Messina et al. first isolated them from subcultures of postnatal atrial or ventricular human biopsy specimens and from murine hearts [174]. They are highly clonogenic and express stem markers such as c-Kit, Sca-1, CD31 and CD34. Although there are controversies about the cardiospheres isolation protocols [175] in rodents where spontaneously beating clusters were suggested to be contaminating myocardial tissues rather than clonogenic, cardiomyogenic cardiac resident stem cells, in vivo studies via transplantation into myocardial infarction models have demonstrated the potential of cardiospheres in cardiac regenerative therapies [176].

\section{Origin of cardiac resident stem cells}

While the presence of cardiac resident stem cells seems promising, several questions still remain open, and these include the origin of cardiac resident stem cells and the mechanisms underlying their in vivo activation and role in tissue repair. The question of the origin of cardiac resident stem cells has been widely debated. One hypothesis portrays the fact that cardiac resident stem cells arise during embryonic cardiogenesis and that they are retained as undifferentiated remnants in putative stem cell populations concentrated mainly in the atria and apex of the heart (Figure 2) $[3,177]$. This is best supported by the organ distribution of Isl1 $1^{+}$cells in the postnatal heart, which match the contributions of its embryonic precursors [172,178]. Furthermore, SP cells have also been found to arise from neural crest cells in the embryonic heart and contribute to development and homeostasis of cardiac tissue [179]. The second hypothesis supported by many other studies suggest that cardiac resident stem cells stem from an extra-cardiac pool of circulating progenitors coming from the bone marrow and are able to home to the heart upon stimulation. This was first demonstrated by sex-mismatched bone marrow and cardiac transplantations in which recipients show a high level of chimerism in their hearts [180]. As previously described, cardiac resident stem cells have also been characterized by the expression of markers commonly used to isolate bonemarrow hematopoietic stem cells and have been shown by several groups to contribute to the pool of cardiac progenitors $[162,181]$.

\section{Stem Cell-Based Cellular Therapy for Heart Regeneration}

There have been already several ongoing clinical trials for cardiac repair whereby bone marrow-derived cells or peripheral blood-derived endothelial progenitor cells were transplanted via intra-coronary cell infusion or direct intra-myocardial injection in patients after myocardial infarction [182-184]. Although the initial trials assure the safety and feasibility of using bonemarrow cell transplantation for cardiac therapy, the results are still somewhat ambiguous as demonstrated by the STEMI (ST-Elevation acute Myocardial Infarction) and the ASTAMI (Autologous Stem Cell Transplantation in Acute Myocardial Infarction) trials [184,185]. Challenges for bonemarrow related applications in cellular therapy still need to be overcome as the efficiency of regeneration to myocardial tissue is still insignificant.

Previous studies, which examined the use of fetal or neonatal cardiomyocytes as donor cells clearly established that exogenous cardiomyocytes can structurally and functionally integrate into the host myocardium [186]. However, there is no accessibility of fetal or neonatal sources for treating patients. The ethical and immune rejection concerns also make this therapy not practical. Therefore, recent focus has been placed on cardiac resident stem cells, or CPCs and cardiomyocytes derived from pluripotent stem cells.

\section{Cardiac resident stem cells for cardiac repair}

Previous studies showed that human cardiac resident stem cells could be activated within the cardiac niche to renew themselves after myocardial infarction [177], overcoming the problems of cell loss after cellular implantation. Cardiospheres or cardiosphere-derived cardiac progenitor cells have already found their way into clinical trials (CADUCEUS; cardiosphere derived autologous stem cells to reverse ventricular dysfunction) to demonstrate the applicability of these cells by intra-coronary injection into patients with ischemic left ventricular dysfunction and myocardial infarction [187]. However, the longterm clinical outcome needs to be further investigated. In conclusion, although cardiac resident stem cells remain an attractive candidate for the use in regenerative therapies in the treatment of heart failure, their functional significance under physiological and pathological states remains to be elucidated. Future studies on regulatory mechanisms determining self-renewal and differentiation of these cells would improve our understanding of cardiac biology and hopefully foster our knowledge in the development of cardiac resident stemcell-based therapy.

\section{Selection and therapeutic potential of CPCs derived from pluripotent stem cells}

Heart regeneration requires the formation of cardiomyocytes and coronary vessels, and it can most likely not be accomplished by a cell already committed to one specific lineage. Thus, it is necessary to use cells that are multipotent and can differentiate into functional cardiomyocytes as well as vascular smooth muscle and endothelial cells. As mentioned above, CPCs (Isl1 $\left.1^{+} / \mathrm{Nkx} 2-5^{+}\right)$derived from pluripotent stem cells can satisfy the need for multi-lineage differentiation. For cellular therapy, however, one of prerequisites is to generate sufficient numbers of the desired cell type with high purity.The formation of teratomas after transplantation of undifferentiated pluripotent stem cells [188] implies that it is essential to purify pluripotent stem cellderived CPCs before transplantation.

A recent study demonstrated that the combination of cell surface markers Flt1 and Flt4 could contribute to the enrichment for Isl1 ${ }^{+}$ $\mathrm{Nkx} 2-5^{+}$CPCswith tri-lineage cardiovascular potentialin mouse embryonic hearts and differentiating iPSCs [189]. The purified CPCs could be propagated in vitro while simultaneously maintaining their multipotent differentiation potential in the presence of the $\beta$-catenin/ p300 inhibitor IQ-1 and the ROCK-inhibitor Thiazovivin. Furthermore, the purified CPCs were successfully transplanted into the healthy heart and showed the capacity to engraft into the native tissue with robust differentiation ofcardiomyocytes which are morphologically and electrophysiologically mature [189]. In addition, these CPCs can also differentiate into smooth muscle cells in the normal heart [189]. As a proof of concept for cardiac repair, Mauritz et al. evaluated the 
potential of mouse iPSC-derived $\mathrm{Flk1}^{+} \mathrm{CPCs}$ to restore myocardial tissue and improve cardiac function after acute myocardial infarction in mice [190]. Flk1 ${ }^{+}$CPCs formed remarkable grafts only two weeks after cell transplantation in vivo, suggesting their rapid proliferation capacity, therefore raising questions as to whether such proliferation could be controlled in vivo.

CPCs have also been derived from human ESCs by the addition of activin A, BMP4, bFGF, VEGF and Dkk1 in a time- and dosedependent manner during in vitro differentiation [130]. The $\mathrm{KDR}^{\mathrm{low} /}$ c-Kit population expresses high levels of genes involved in cardiac development, including $N k \times 2-5$, Isl 1 and Tbx5, and displays potential to differentiate into cardiac, endothelial and vascular smooth muscle cells in vitro [130]. In contrast, the $\mathrm{KDR}^{\mathrm{high}} / \mathrm{c}-\mathrm{Kit}^{+}$population expresses high levels of genes and proteins associated with vascular development [130]. Transplantation of $\mathrm{KDR}^{\text {low }} / \mathrm{c}$-Kit cells into normal and infarcted hearts of immunodeficient mice showed that these cells were able to differentiate into the cardiac, endothelial and vascular smooth muscle lineages and to improve cardiac function in vivo. In addition, no teratomas were observed in any of the transplanted animals [130]. Human iPSC-derived CPCs transplanted into the infarcted rat hearts revealed engraftment, differentiation into cardiomyocytes and smooth muscle, and persisted for at least 10 weeks post cell injection, thereby resulted in a non-significant trend toward protection from decline in function after ischemic damage [191]. Although such cell transplantation does improve function, the mechanisms mediating this effect are largely not known [192]. Future in vitro studies on expansion of human pluripotent stem cell-derived CPCs should also be performed to meet the needs of cellular therapy. In addition, the safety and effectiveness using CPCs should be assessed using large animals as preclinical models. The differentiation and maturation of these cells in vivo need to be studied. Methods for the cell administration into damaged hearts should be optimized. CPCs might be most suitable for tissue engineering approaches that will allow for directed differentiation as well as control of proliferation and maturation in vitro before transplantation.

\section{Pluripotent stem cell-derived cardiomyocytes in transplantation studies}

ESCs are the first pluripotent stem cell source that could reliably give rise to cardiomyocytes. The use of patient-specific iPSCs for generation of cardiomyocytes for cardiac repair could overcome the ethical and immunological complications associated with human ESCs. Transplantation of purified cardiomyocytes derived from pluripotent stem cells may limit the oncogenic risk of injecting undifferentiated iPSCs or ESCs. However, the ability to utilize cardiomyocytes derived from human iPSCs/ESCs therapeutically will require efficient induction of cardiomyocyte lineages from pluripotent stem cells, the identification of surface markers to enrich for cardiomyocytes without genetic manipulation, and elimination of any residual pluripotent stem cells.

As mentioned above, the efficient induction of cardiomyocytes from pluripotent stem cells in vitro can be achieved by manipulation of signaling pathways that play important roles during mesodermal and cardiac development using factors and small molecules. Numerous protocols have been described enabling the production of a large number of cardiomyocytes. Uosaki et al. provided an important tool for the purification of pluripotent stem cell-derived cardiomyocytes. They used a differentiation system to screen 242 antibodies for surface markers of cardiomyocytes and found VCAM1 as a suitable candidate.
It has been shown that 95\% of MACS-purified VCAM1-positive cells were positive for cardiac muscle troponin $\mathrm{T}$ [131].

A number of reports have shown that human ESC-derived cardiomyocytes proliferate after transplantation into infarcted rodent hearts, form human myocardial grafts, and enhance regional and global contractile function [118,193-195]. These first experiments showed that transplanted cardiomyocytes can survive in the recipient, that they can in principle couple to host cardiomyocytes and that they have at least the ability to attenuate myocardial infarction for certain time. However, a major problem identified in almost all cardiomyocytes transplantation studies in animal models, is the relatively poor survival of the engrafted cells, which impact the effectiveness of the transplantation of pluripotent stem cell-derived cardiomyocytes. Therefore, systematic approaches to prevent transplanted cell death in cardiac repair are still necessary [196].

\section{Therapeutic potential of direct conversion of fibroblasts into cardiomyocytes}

The path for an entirely different approach was paved in 2010 when Ieda et al. reprogrammed cardiac and tail-tip fibroblasts with the transcription factors GATA4, MEF2C and Tbx5 (GMT) to induced cardiomyocytes without passing through a pluripotent stage [197]. The induced cardiomyocytes expressed cardiac markers, showed well-defined sarcomeric structures and contracted spontaneously. Importantly, the fibroblasts after viral transduction could be also converted into cardiomyocytes in vivo [197]. Moreover, in vivo delivery of GMT into the myocardium after coronary ligation attenuated ejection fraction and stroke volume decline after three months. The scar area was significantly reduced and induced cardiomyocytes were detected in the scar area [198]. The addition of the transcription factor Hand2 to the GMT (GHMT) resulted inincreased generation of induced cardiomyocytes from both cardiac and tail-tip fibroblasts. When the GHMT retroviruses were delivered into the heart after myocardial infarction, the cardiac function was improved and the adverse ventricular remodeling was reduced. By comparison, functional improvement was accelerated and more complete with GHMT than GMT [199]. Jayawardena et al. used transient expression of miRNAs 1, 133, 208 and 499 in combination with JAK Inhibitor I to convert 14\% of cardiac fibroblasts into a-MHC positive cardiomyocytes which exhibit spontaneous calcium oscillations and prominent striations [200] Moreover, when delivered with a lentivirus in a ligated mouse heart, the miRNA combination induced trans-differentiation of fibroblasts to well-integrated, striated cardiomyocytes [200]. Taken together, these studies provide proof of principle for the possibility of in vivo transdifferentiation of cardiac fibroblasts into functional cardiomyocytes and may have broad and important implicationsformyocardial regeneration therapy.

\section{Conclusion}

If the massive cardiac cell loss resulting from myocardial infarction could be replaced by the functional cardiomyocytes and revascularization could occur, millions of patients' life can be rescued every year. Studies on patient-specific iPSCs prove that they are an excellent tool for disease modeling, drug discovery and cardiotoxicity screenings. Importantly, this technology also provides an invaluable source for generation of patient-specific cardiomyocytes, vascular smooth muscle and endothelial cells which can be used for regeneration of the damaged heart. However, extensive basic research and well-designed clinical trials have yet to be performed to better understand the biology of stem cell-based therapy, to develop more 
efficient methods for the cell administration into damaged hearts, to improve the survival and integration of the transplanted cells, and to demonstrate the safety. Recently, cardiac tissue engineering has made rapid progress. By using different strategies, such as myocardial patches and whole organ decellularization-recellularization, stem-cell based cardiac therapy could be expanded to treat non-ischemic heart disease, such as congenital heart diseases and acquired heart defects. In addition, further studies are required to elucidate the safety and effectiveness of cardiac repair by reprogramming of endogenous non-cardiomyocytes towards a cardiomyocyte fate in vivo through forced expression of different transcription factor or microRNA combinations.

\section{Acknowledgement}

The authors' studies supported by the Deutsche Forschungsgemeinschaft (GU 595/2-1), SFB 1002 (K.G.) and IRTG1816 (K.G.) and by the Anschubsfinanzierung from Universitätsmedizin Göttingen (K.G.). We acknowledge support by the German Research Foundation and the Open Access Publication Funds of the Göttingen University.

\section{References}

1. Bruneau BG (2008) The developmental genetics of congenital heart disease. Nature 451: 943-948.

2. Bergmann O, Bhardwaj RD, Bernard S, Zdunek S, Barnabé-Heider F, et al. (2009) Evidence for cardiomyocyte renewal in humans. Science 324: 98-102.

3. Beltrami AP, Barlucchi L, Torella D, Baker M, Limana F, et al. (2003) Adult cardiac stem cells are multipotent and support myocardial regeneration. Cell 114: 763-776.

4. Oh H, Bradfute SB, Gallardo TD, Nakamura T, Gaussin V, et al. (2003) Cardiac progenitor cells from adult myocardium: homing, differentiation, and fusion after infarction. Proc Natl Acad Sci U S A 100: 12313-12318.

5. Kajstura J, Rota M, Cappetta D, Ogórek B, Arranto C, et al. (2012) Cardiomyogenesis in the aging and failing human heart. Circulation 126: 18691881.

6. Passier R, van Laake LW, Mummery CL (2008) Stem-cell-based therapy and lessons from the heart. Nature 453: 322-329.

7. Laflamme MA, Murry CE (2011) Heart regeneration. Nature 473: 326-335.

8. Porrello ER, Mahmoud Al, Simpson E, Hill JA, Richardson JA, et al. (2011) Transient regenerative potential of the neonatal mouse heart. Science 331 : 1078-1080.

9. Zhu W, Hassink RJ, Rubart M, Field LJ (2009) Cell-cycle-based strategies to drive myocardial repair. Pediatr Cardiol 30: 710-715.

10. Amabile G, Meissner A (2009) Induced pluripotent stem cells: current progress and potential for regenerative medicine. Trends Mol Med 15: 59-68.

11. Garry DJ, Olson EN (2006) A common progenitor at the heart of development. Cell 127: 1101-1104

12. Wu SM, Fujiwara Y, Cibulsky SM, Clapham DE, Lien CL, et al. (2006) Developmental origin of a bipotential myocardial and smooth muscle cell precursor in the mammalian heart. Cell 127: 1137-1150.

13. Laugwitz KL, Moretti A, Caron L, Nakano A, Chien KR (2008) Islet1 cardiovascular progenitors: a single source for heart lineages? Development 135: 193-205.

14. Srivastava D (2006) Making or breaking the heart: from lineage determination to morphogenesis. Cell 126: 1037-1048.

15. Tam PP, Parameswaran M, Kinder SJ, Weinberger RP (1997) The allocation of epiblast cells to the embryonic heart and other mesodermal lineages: the role of ingression and tissue movement during gastrulation. Development 124: $1631-1642$.

16. Harvey RP (2002) Patterning the vertebrate heart. Nat Rev Genet 3: 544-556.

17. Meilhac SM, Esner M, Kelly RG, Nicolas JF, Buckingham ME (2004) The clonal origin of myocardial cells in different regions of the embryonic mouse heart. Dev Cell 6: 685-698.

18. Vincent SD, Buckingham ME (2010) How to make a heart: the origin and regulation of cardiac progenitor cells. Curr Top Dev Biol 90: 1-41.
19. Kattman SJ, Huber TL, Keller GM (2006) Multipotent flk-1+ cardiovascular progenitor cells give rise to the cardiomyocyte, endothelial, and vascular smooth muscle lineages. Dev Cell 11: 723-732.

20. Martin-Puig S, Wang Z, Chien KR (2008) Lives of a heart cell: tracing the origins of cardiac progenitors. Cell Stem Cell 2: 320-331.

21. Moretti A, Caron L, Nakano A, Lam JT, Bernshausen A, et al. (2006) Multipotent embryonic isl1+ progenitor cells lead to cardiac, smooth muscle and endothelial cell diversification. Cell 127: 1151-1165.

22. Buckingham M, Meilhac S, Zaffran S (2005) Building the mammalian heart from two sources of myocardial cells. Nat Rev Genet 6: 826-835.

23. Soufan AT, van den Berg G, Ruijter JM, de Boer PA, van den Hoff MJ, et al. (2006) Regionalized sequence of myocardial cell growth and proliferation characterizes early chamber formation. Circ Res 99: 545-552.

24. van den Berg G, Abu-Issa R, de Boer BA, Hutson MR, de Boer PA, et al. (2009) A caudal proliferating growth center contributes to both poles of the forming heart tube. Circ Res 104: 179-188.

25. Wagner M, Siddiqui MA (2007) Signal transduction in early heart development (I): cardiogenic induction and heart tube formation. Exp Biol Med (Maywood) 232: 852-865

26. Hamada H, Meno C, Watanabe D, Saijoh Y (2002) Establishment of vertebrate left-right asymmetry. Nat Rev Genet 3: 103-113.

27. Harvey RP (1998) Cardiac looping--an uneasy deal with laterality. Semin Cell Dev Biol 9: 101-108.

28. Epstein JA (2010) Franklin H. Epstein Lecture. Cardiac development and implications for heart disease. N Engl J Med 363: 1638-1647

29. Dhanantwari P, Lee E, Krishnan A, Samtani R, Yamada S, et al. (2009) Human cardiac development in the first trimester: a high-resolution magnetic resonance imaging and episcopic fluorescence image capture atlas. Circulation 120: 343351.

30. Roche P, Czubryt MP, Wigle JT (2013) Molecular Mechanisms of Cardiac Development. In: Ostadal B, Dhalla, N.S. ed. Cardiac Adaptations: Molecular Mechanisms Springer Science+Business Media New York; 19-39.

31. Tam PP, Loebel DA (2007) Gene function in mouse embryogenesis: get set for gastrulation. Nat Rev Genet 8: 368-381.

32. Burridge PW, Keller G, Gold JD, Wu JC (2012) Production of de novo cardiomyocytes: human pluripotent stem cell differentiation and direct reprogramming. Cell Stem Cell 10: 16-28.

33. Bondue A, Lapouge G, Paulissen C, Semeraro C, lacovino M, et al. (2008) Mesp1 acts as a master regulator of multipotent cardiovascular progenitor specification. Cell Stem Cell 3: 69-84.

34. Costello I, PimeisI IM, Dräger S, Bikoff EK, Robertson EJ, et al. (2011) The T-box transcription factor Eomesodermin acts upstream of Mesp1 to specify cardiac mesoderm during mouse gastrulation. Nat Cell Biol 13: 1084-1091.

35. Cohen ED, Tian Y, Morrisey EE (2008) Wnt signaling: an essential regulato of cardiovascular differentiation, morphogenesis and progenitor self-renewal. Development 135: 789-798.

36. Marvin MJ, Di Rocco G, Gardiner A, Bush SM, Lassar AB (2001) Inhibition of Wnt activity induces heart formation from posterior mesoderm. Genes Dev 15 316-327.

37. Naito AT, Shiojima I, Akazawa H, Hidaka K, Morisaki T, et al. (2006) Developmental stage-specific biphasic roles of Wnt/beta-catenin signaling in cardiomyogenesis and hematopoiesis. Proc Natl Acad Sci U S A 103: 19812 19817.

38. Barron M, Gao M, Lough J (2000) Requirement for BMP and FGF signaling during cardiogenic induction in non-precardiac mesoderm is specific, transient and cooperative. Dev Dyn 218: 383-393.

39. Eisenberg CA, Eisenberg LM (1999) WNT11 promotes cardiac tissue formation of early mesoderm. Dev Dyn 216: 45-58.

40. Lopez-Sanchez C, Climent V, Schoenwolf GC, Alvarez IS, Garcia-Martinez $\checkmark$ (2002) Induction of cardiogenesis by Hensen's node and fibroblast growth factors. Cell Tissue Res 309: 237-249.

41. Schneider VA, Mercola M (2001) Wnt antagonism initiates cardiogenesis in Xenopus laevis. Genes Dev 15: 304-315. 
42. Pandur $P$, Läsche $M$, Eisenberg LM, Kühl M (2002) Wnt-11 activation of a noncanonical Wnt signalling pathway is required for cardiogenesis. Nature 418 636-641.

43. Reifers F, Walsh EC, Léger S, Stainier DY, Brand M (2000) Induction and differentiation of the zebrafish heart requires fibroblast growth factor 8 (fgf8/ acerebellar). Development 127: 225-235.

44. Schultheiss TM, Burch JB, Lassar AB (1997) A role for bone morphogenetic proteins in the induction of cardiac myogenesis. Genes Dev 11: 451-462.

45. Zhang XM, Ramalho-Santos M, McMahon AP (2001) Smoothened mutants reveal redundant roles for Shh and Ihh signaling including regulation of $L / R$ asymmetry by the mouse node. Cell 105: 781-792.

46. Brand T (2003) Heart development: molecular insights into cardiac specification and early morphogenesis. Dev Biol 258: 1-19.

47. Solloway MJ, Harvey RP (2003) Molecular pathways in myocardial development: a stem cell perspective. Cardiovasc Res 58: 264-277.

48. Tzahor E, Lassar AB (2001) Wnt signals from the neural tube block ectopic cardiogenesis. Genes Dev 15: 255-260.

49. Lindsley RC, Gill JG, Murphy TL, Langer EM, Cai M, et al. (2008) Mesp1 coordinately regulates cardiovascular fate restriction and epithelialmesenchymal transition in differentiating ESCs. Cell Stem Cell 3: 55-68.

50. Saga Y, Miyagawa-Tomita S, Takagi A, Kitajima S, Miyazaki Ji, et al. (1999) MesP1 is expressed in the heart precursor cells and required for the formation of a single heart tube. Development 126: 3437-3447.

51. Wu SM (2008) Mesp1 at the heart of mesoderm lineage specification. Cell Stem Cell 3: 1-2.

52. Bondue A, Blanpain C (2010) Mesp1: a key regulator of cardiovascular lineage commitment. Circ Res 107: 1414-1427.

53. David R, Brenner C, Stieber J, Schwarz F, Brunner S, et al. (2008) MesP1 drives vertebrate cardiovascular differentiation through Dkk-1-mediated blockade of Wnt-signalling. Nat Cell Biol 10: 338-345.

54. Searcy RD, Vincent EB, Liberatore CM, Yutzey KE (1998) A GATA-dependent nkx-2.5 regulatory element activates early cardiac gene expression in transgenic mice. Development 125: 4461-4470.

55. Tanaka M, Chen Z, Bartunkova S, Yamasaki N, Izumo S (1999) The cardiac homeobox gene Csx/Nkx2.5 lies genetically upstream of multiple genes essential for heart development. Development 126: 1269-1280.

56. Kuo CT, Morrisey EE, Anandappa R, Sigrist K, Lu MM, et al. (1997) GATA4 transcription factor is required for ventral morphogenesis and heart tube formation. Genes Dev 11: 1048-1060.

57. Molkentin JD, Lin Q, Duncan SA, Olson EN (1997) Requirement of the transcription factor GATA4 for heart tube formation and ventral morphogenesis. Genes Dev 11: 1061-1072.

58. Watt AJ, Battle MA, Li J, Duncan SA (2004) GATA4 is essential for formation of the proepicardium and regulates cardiogenesis. Proc Natl Acad Sci U S A 101: 12573-12578.

59. Zeisberg EM, Ma Q, Juraszek AL, Moses K, Schwartz RJ, et al. (2005) Morphogenesis of the right ventricle requires myocardial expression of Gata4. $\mathrm{J}$ Clin Invest 115: 1522-1531.

60. Zhou P, He A, Pu WT (2012) Regulation of GATA4 transcriptional activity in cardiovascular development and disease. Curr Top Dev Biol 100: 143-169.

61. Molkentin JD, Antos C, Mercer B, Taigen T, Miano JM, et al. (2000) Direct activation of a GATA6 cardiac enhancer by Nkx2.5: evidence for a reinforcing regulatory network of Nkx2.5 and GATA transcription factors in the developing heart. Dev Biol 217: 301-309.

62. Schwartz RJ, Olson EN (1999) Building the heart piece by piece: modularity of cis-elements regulating Nkx2-5 transcription. Development 126: 4187-4192.

63. Takeuchi JK, Bruneau BG (2009) Directed transdifferentiation of mouse mesoderm to heart tissue by defined factors. Nature 459: 708-711.

64. Belaguli NS, Sepulveda JL, Nigam V, Charron F, Nemer M, et al. (2000) Cardiac tissue enriched factors serum response factor and GATA-4 are mutual coregulators. Mol Cell Biol 20: 7550-7558.

65. Garg V, Kathiriya IS, Barnes R, Schluterman MK, King IN, et al. (2003) GATA4 mutations cause human congenital heart defects and reveal an interaction with TBX5. Nature 424: 443-447.
66. Maitra M, Schluterman MK, Nichols HA, Richardson JA, Lo CW, et al. (2009) Interaction of Gata4 and Gata6 with Tbx5 is critical for normal cardiac development. Dev Biol 326: 368-377.

67. Sepulveda JL, Belaguli N, Nigam V, Chen CY, Nemer M, et al. (1998) GATA-4 and Nkx-2.5 coactivate Nkx-2 DNA binding targets: role for regulating early cardiac gene expression. Mol Cell Biol 18: 3405-3415.

68. Pashmforoush M, Lu JT, Chen H, Amand TS, Kondo R, et al. (2004) Nkx2-5 pathways and congenital heart disease; loss of ventricular myocyte lineage specification leads to progressive cardiomyopathy and complete heart block. Cell 117: 373-386.

69. Schott JJ, Benson DW, Basson CT, Pease W, Silberbach GM, et al. (1998) Congenital heart disease caused by mutations in the transcription factor NKX2 5. Science 281: 108-111.

70. Edmondson DG, Lyons GE, Martin JF, Olson EN (1994) Mef2 gene expression marks the cardiac and skeletal muscle lineages during mouse embryogenesis. Development 120: 1251-1263.

71. Kolodziejczyk SM, Wang L, Balazsi K, DeRepentigny Y, Kothary R, et al. (1999) MEF2 is upregulated during cardiac hypertrophy and is required for normal post-natal growth of the myocardium. Curr Biol 9: 1203-1206.

72. Lin Q, Schwarz J, Bucana C, Olson EN (1997) Control of mouse cardiac morphogenesis and myogenesis by transcription factor MEF2C. Science 276 1404-1407.

73. Kodo K, Nishizawa T, Furutani M, Arai S, Ishihara K, et al. (2012) Genetic analysis of essential cardiac transcription factors in 256 patients with nonsyndromic congenital heart defects. Circ J 76: 1703-1711.

74. Brown DD, Martz SN, Binder O, Goetz SC, Price BM, et al. (2005) Tbx5 and Tbx20 act synergistically to control vertebrate heart morphogenesis. Development 132: 553-563.

75. Bruneau BG, Logan M, Davis N, Levi T, Tabin CJ, et al. (1999) Chamberspecific cardiac expression of Tbx5 and heart defects in Holt-Oram syndrome. Dev Biol 211: 100-108.

76. Bruneau BG, Nemer G, Schmitt JP, Charron F, Robitaille L, et al. (2001) A murine model of Holt-Oram syndrome defines roles of the T-box transcription factor Tbx5 in cardiogenesis and disease. Cell 106: 709-721.

77. Horb ME, Thomsen GH (1999) Tbx5 is essential for heart development Development 126: 1739-1751.

78. Liberatore CM, Searcy-Schrick RD, Yutzey KE (2000) Ventricular expression of tbx5 inhibits normal heart chamber development. Dev Biol 223: 169-180.

79. Firulli AB, McFadden DG, Lin Q, Srivastava D, Olson EN (1998) Heart and extra-embryonic mesodermal defects in mouse embryos lacking the bHLH transcription factor Hand1. Nat Genet 18: 266-270.

80. Firulli BA, Hadzic DB, McDaid JR, Firulli AB (2000) The basic helix-loop-helix transcription factors dHAND and eHAND exhibit dimerization characteristics that suggest complex regulation of function. J Biol Chem 275: 33567-33573.

81. Risebro CA, Smart N, Dupays L, Breckenridge R, Mohun TJ, et al. (2006) Hand1 regulates cardiomyocyte proliferation versus differentiation in the developing heart. Development 133: 4595-4606.

82. Yamagishi $\mathrm{H}$, Yamagishi $\mathrm{C}$, Nakagawa O, Harvey RP, Olson EN, et al. (2001) The combinatorial activities of Nkx2.5 and dHAND are essential for cardiac ventricle formation. Dev Biol 239: 190-203.

83. Biben C, Harvey RP (1997) Homeodomain factor Nkx2-5 controls left/righ asymmetric expression of bHLH gene eHand during murine heart development. Genes Dev 11: 1357-1369.

84. Srivastava D, Thomas T, Lin Q, Kirby ML, Brown D, et al. (1997) Regulation of cardiac mesodermal and neural crest development by the bHLH transcription factor, dHAND. Nat Genet 16: 154-160.

85. Cai CL, Liang X, Shi Y, Chu PH, Pfaff SL, et al. (2003) Isl1 identifies a cardiac progenitor population that proliferates prior to differentiation and contributes a majority of cells to the heart. Dev Cell 5: 877-889.

86. Ma Q, Zhou B, Pu WT (2008) Reassessment of IsI1 and Nkx2-5 cardiac fate maps using a Gata4-based reporter of Cre activity. Dev Biol 323: 98-104.

87. Prall OW, Menon MK, Solloway MJ, Watanabe Y, Zaffran S, et al. (2007) An Nkx2-5/Bmp2/Smad1 negative feedback loop controls heart progenitor specification and proliferation. Cell 128: 947-959. 
88. Sun Y, Liang X, Najafi N, Cass M, Lin L, et al. (2007) Islet 1 is expressed in distinct cardiovascular lineages, including pacemaker and coronary vascular cells. Dev Biol 304: 286-296.

89. Kwon C, Qian L, Cheng P, Nigam V, Arnold J, et al. (2009) A regulatory pathway involving Notch1/beta-catenin/Is/1 determines cardiac progenitor cell fate. Nat Cell Biol 11: 951-957.

90. Kwon C, Arnold J, Hsiao EC, Taketo MM, Conklin BR, et al. (2007) Canonica Wnt signaling is a positive regulator of mammalian cardiac progenitors. Proc Natl Acad Sci U S A 104: 10894-10899.

91. Dodou E, Verzi MP, Anderson JP, Xu SM, Black BL (2004) Mef2c is a direct transcriptional target of ISL1 and GATA factors in the anterior heart field during mouse embryonic development. Development 131: 3931-3942.

92. Kang J, Nathan E, Xu SM, Tzahor E, Black BL (2009) Isl1 is a direct transcriptional target of Forkhead transcription factors in second-heart-fieldderived mesoderm. Dev Biol 334: 513-522.

93. von Both I, Silvestri C, Erdemir T, Lickert H, Walls JR, et al. (2004) Foxh1 is essential for development of the anterior heart field. Dev Cell 7: 331-345.

94. Chen L, Fulcoli FG, Ferrentino R, Martucciello S, Illingworth EA, et al. (2012) Transcriptional control in cardiac progenitors: Tbx1 interacts with the BAF chromatin remodeling complex and regulates Wnt5a. PLoS Genet 8: e1002571.

95. Hu T, Yamagishi H, Maeda J, McAnally J, Yamagishi C, et al. (2004) Tbx1 regulates fibroblast growth factors in the anterior heart field through a reinforcing autoregulatory loop involving forkhead transcription factors. Development 131 : 5491-5502.

96. Lindsay EA, Vitelli F, Su H, Morishima M, Huynh T, et al. (2001) Tbx1 haploinsufficieny in the DiGeorge syndrome region causes aortic arch defects in mice. Nature 410: 97-101.

97. Maeda J, Yamagishi H, McAnally J, Yamagishi C, Srivastava D (2006) Tbx1 is regulated by forkhead proteins in the secondary heart field. Dev Dyn 235: 701-710.

98. Merscher S, Funke B, Epstein JA, Heyer J, Puech A, et al. (2001) TBX1 is responsible for cardiovascular defects in velo-cardio-facial/DiGeorge syndrome. Cell 104: 619-629.

99. Xu H, Morishima M, Wylie JN, Schwartz RJ, Bruneau BG, et al. (2004) Tbx1 has a dual role in the morphogenesis of the cardiac outflow tract. Development 131: 3217-3227.

100. Chen L, Fulcoli FG, Tang S, Baldini A (2009) Tbx1 regulates proliferation and differentiation of multipotent heart progenitors. Circ Res 105: 842-851.

101. Bu L, Jiang X, Martin-Puig S, Caron L, Zhu S, et al. (2009) Human ISL1 hear progenitors generate diverse multipotent cardiovascular cell lineages. Nature 460: 113-117.

102. Huynh T, Chen L, Terrell P, Baldini A (2007) A fate map of Tbx1 expressing cells reveals heterogeneity in the second cardiac field. Genesis 45: 470-475.

103.Zhao Y, Samal E, Srivastava D (2005) Serum response factor regulates a muscle-specific microRNA that targets Hand2 during cardiogenesis. Nature 436: $214-220$.

104. High FA, Jain R, Stoller JZ, Antonucci NB, Lu MM, et al. (2009) Murine Jagged1/ Notch signaling in the second heart field orchestrates Fgf8 expression and tissue-tissue interactions during outflow tract development. J Clin Invest 119: 1986-1996.

105. Klaus A, Saga Y, Taketo MM, Tzahor E, Birchmeier W (2007) Distinct roles of Wnt/beta-catenin and Bmp signaling during early cardiogenesis. Proc Natl Acad Sci U S A 104: 18531-18536.

106. Park EJ, Ogden LA, Talbot A, Evans S, Cai CL, et al. (2006) Required, tissuespecific roles for Fgf8 in outflow tract formation and remodeling. Development 133: $2419-2433$.

107.Park EJ, Watanabe Y, Smyth G, Miyagawa-Tomita S, Meyers E, et al. (2008) An FGF autocrine loop initiated in second heart field mesoderm regulates morphogenesis at the arterial pole of the heart. Development 135: 3599-3610.

108. Tirosh-Finkel L, Elhanany H, Rinon A, Tzahor E (2006) Mesoderm progenito cells of common origin contribute to the head musculature and the cardiac outflow tract. Development 133: 1943-1953

109. Uchimura T, Komatsu Y, Tanaka M, McCann KL, Mishina Y (2009) Bmp2 and Bmp4 genetically interact to support multiple aspects of mouse development including functional heart development. Genesis 47: 374-384.
110. Itskovitz-Eldor J, Schuldiner M, Karsenti D, Eden A Yanuka O, et al. (2000) Differentiation of human embryonic stem cells into embryoid bodies compromising the three embryonic germ layers. Mol Med 6: 88-95.

111. Kehat I, Kenyagin-Karsenti D, Snir M, Segev H, Amit M, et al. (2001) Human embryonic stem cells can differentiate into myocytes with structural and functional properties of cardiomyocytes. J Clin Invest 108: 407-414.

112. Mummery C, Ward-van Oostwaard D, Doevendans P, Spijker R, van den Brink S, et al. (2003) Differentiation of human embryonic stem cells to cardiomyocytes: role of coculture with visceral endoderm-like cells. Circulation 107: 2733-2740.

113. Fujiwara M, Yan P, Otsuji TG, Narazaki G, Uosaki H, et al. (2011) Induction and enhancement of cardiac cell differentiation from mouse and human induced pluripotent stem cells with cyclosporin-A. PLoS One 6: e16734.

114. Passier R, Oostwaard DW, Snapper J, Kloots J, Hassink RJ, et al. (2005) Increased cardiomyocyte differentiation from human embryonic stem cells in serum-free cultures. Stem Cells 23: 772-780.

115. David R, Jarsch VB, Schwarz F, Nathan P, Gegg M, et al. (2011) Induction of MesP1 by Brachyury $(\mathrm{T})$ generates the common multipotent cardiovascular stem cell. Cardiovasc Res 92: 115-122.

116. Hiroi Y, Kudoh S, Monzen K, Ikeda Y, Yazaki Y, et al. (2001) Tbx5 associates with Nkx2-5 and synergistically promotes cardiomyocyte differentiation. Nat Genet 28: 276-280

117. Takei S, Ichikawa H, Johkura K, Mogi A, No H, et al. (2009) Bone morphogenetic protein-4 promotes induction of cardiomyocytes from human embryonic stem cells in serum-based embryoid body development. Am J Physiol Heart Circ Physiol 296: H1793-1803.

118. Laflamme MA, Chen KY, Naumova AV, Muskheli V, Fugate JA, et al. (2007) Cardiomyocytes derived from human embryonic stem cells in pro-survival factors enhance function of infarcted rat hearts. Nat Biotechnol 25: 1015-1024.

119. Paige SL, Osugi T, Afanasiev OK, Pabon L, Reinecke H, et al. (2010) Endogenous Wnt/ß-Catenin Signaling Is Required for Cardiac Differentiation in Human Embryonic Stem Cells. PLoS One 5: e11134.

120. Burridge PW, Thompson S, Millrod MA, Weinberg S, Yuan X, et al. (2011) A universal system for highly efficient cardiac differentiation of human induced pluripotent stem cells that eliminates interline variability. PLoS One 6: e18293.

121. Burridge PW, Anderson D, Priddle H, Barbadillo Munoz MD, Chamberlain S, et al. (2007) Improved human embryonic stem cell embryoid body homogeneity and cardiomyocyte differentiation from a novel $\mathrm{V}-96$ plate aggregation system highlights interline variability. Stem Cells 25: 929-938.

122. Tran TH, Wang X, Browne C, Zhang Y, Schinke M, et al. (2009) Wnt3ainduced mesoderm formation and cardiomyogenesis in human embryonic stem cells. Stem Cells 27: 1869-1878.

123. Elliott DA, Braam SR, Koutsis K, Ng ES, Jenny R, et al. (2011) NKX2-5(eGFP/w) hESCs for isolation of human cardiac progenitors and cardiomyocytes. Nat Methods 8: 1037-1040.

124. Jang J, Ku SY, Kim JE, Choi K, Kim YY, et al. (2008) Notch inhibition promotes human embryonic stem cell-derived cardiac mesoderm differentiation. Stem Cells 26: 2782-2790.

125. Schroeder T, Kohlhof H, Rieber N, Just U (2003) Notch signaling induces multilineage myeloid differentiation and up-regulates PU.1 expression. J Immunol 170: 5538-5548.

126. Xu XQ, Graichen R, Soo SY, Balakrishnan T, Rahmat SN, et al. (2008) Chemically defined medium supporting cardiomyocyte differentiation of human embryonic stem cells. Differentiation 76: 958-970.

127. Freund C, Ward-van Oostwaard D, Monshouwer-Kloots J, van den Brink S van Rooijen M, et al. (2008) Insulin redirects differentiation from cardiogenic mesoderm and endoderm to neuroectoderm in differentiating human embryonic stem cells. Stem Cells 26: 724-733.

128. Lian X, Zhang J, Azarin SM, Zhu K, Hazeltine LB, et al. (2013) Directed cardiomyocyte differentiation from human pluripotent stem cells by modulating Wnt $/ \hat{I}^{2}$-catenin signaling under fully defined conditions. Nat Protoc 8: 162-175.

129. Lian X, Hsiao C, Wilson G, Zhu K, Hazeltine LB, et al. (2012) Robust cardiomyocyte differentiation from human pluripotent stem cells via tempora modulation of canonical Wnt signaling. Proc Natl Acad Sci U S A 109: E18481857. 
130. Yang L, Soonpaa MH, Adler ED, Roepke TK, Kattman SJ, et al. (2008) Human cardiovascular progenitor cells develop from a KDR+ embryonic-stem-cellderived population. Nature 453: 524-528

131. Uosaki H, Fukushima H, Takeuchi A, Matsuoka S, Nakatsuji N, et al. (2011) Efficient and scalable purification of cardiomyocytes from human embryonic and induced pluripotent stem cells by VCAM1 surface expression. PLoS One 6: e23657.

132. Willems E, Spiering S, Davidovics H, Lanier M, Xia Z, et al. (2011) Smallmolecule inhibitors of the Wnt pathway potently promote cardiomyocytes from human embryonic stem cell-derived mesoderm. Circ Res 109: 360-364.

133. Ren Y, Lee MY, Schliffke S, Paavola J, Amos PJ, et al. (2011) Small molecule Wnt inhibitors enhance the efficiency of BMP-4-directed cardiac differentiation of human pluripotent stem cells. J Mol Cell Cardiol 51: 280-287.

134. Yuasa S, Itabashi Y, Koshimizu U, Tanaka T, Sugimura K, et al. (2005) Transient inhibition of BMP signaling by Noggin induces cardiomyocyte differentiation of mouse embryonic stem cells. Nat Biotechnol 23: 607-611.

135. Ao A, Hao J, Hopkins CR, Hong CC (2012) DMH1, a novel BMP smal molecule inhibitor, increases cardiomyocyte progenitors and promotes cardiac differentiation in mouse embryonic stem cells. PLoS One 7: e41627.

136. Nemir M, Croquelois A Pedrazzini T, Radtke F (2006) Induction of cardiogenesis in embryonic stem cells via downregulation of Notch1 signaling. Circ Res 98: 1471-1478.

137. Schroeder T, Meier-Stiegen F, Schwanbeck R, Eilken H, Nishikawa S, et al (2006) Activated Notch1 alters differentiation of embryonic stem cells into mesodermal cell lineages at multiple stages of development. Mech Dev 123: 570-579.

138. Croquelois A, Domenighetti AA, Nemir M, Lepore M, Rosenblatt-Velin N, et al. (2008) Control of the adaptive response of the heart to stress via the Notch1 receptor pathway. J Exp Med 205: 3173-3185.

139. Collesi C, Zentilin L, Sinagra G, Giacca M (2008) Notch1 signaling stimulates proliferation of immature cardiomyocytes. J Cell Biol 183: 117-128.

140. Ueno S, Weidinger G, Osugi T, Kohn AD, Golob JL, et al. (2007) Biphasic role for Wnt/beta-catenin signaling in cardiac specification in zebrafish and embryonic stem cells. Proc Natl Acad Sci U S A 104: 9685-9690.

141. Koyanagi M, Haendeler J, Badorff C, Brandes RP, Hoffmann J, et al. (2005) Non-canonical Wnt signaling enhances differentiation of human circulating progenitor cells to cardiomyogenic cells. J Biol Chem 280: 16838-16842.

142. Cao N, Liu Z, Chen Z, Wang J, Chen T, et al. (2012) Ascorbic acid enhances the cardiac differentiation of induced pluripotent stem cells through promoting the proliferation of cardiac progenitor cells. Cell Res 22: 219-236.

143. Takahashi T, Lord B, Schulze PC, Fryer RM, Sarang SS, et al. (2003) Ascorbic acid enhances differentiation of embryonic stem cells into cardiac myocytes. Circulation 107: 1912-1916.

144. McDevitt TC, Laflamme MA, Murry CE (2005) Proliferation of cardiomyocytes derived from human embryonic stem cells is mediated via the IGF/PI 3-kinase/ Akt signaling pathway. J Mol Cell Cardiol 39: 865-873.

145. Fischer KM, Din S, Gude N, Konstandin MH, Wu W, et al. (2011) Cardiac progenitor cell commitment is inhibited by nuclear Akt expression. Circ Res 108: 960-970.

146.Zhu WZ, Xie Y, Moyes KW, Gold JD, Askari B, et al. (2010) Neuregulin/ErbB signaling regulates cardiac subtype specification in differentiating human embryonic stem cells. Circ Res 107: 776-786.

147.Zhang Q, Jiang J, Han P, Yuan Q, Zhang J, et al. (2011) Direct differentiation of atrial and ventricular myocytes from human embryonic stem cells by alternating retinoid signals. Cell Res 21: 579-587.

148. Fu JD, Rushing SN, Lieu DK, Chan CW, Kong CW, et al. (2011) Distinct roles of microRNA-1 and -499 in ventricular specification and functional maturation of human embryonic stem cell-derived cardiomyocytes. PLoS One 6: e27417.

149. Sluijter JP, van Mil A, van Vliet P, Metz CH, Liu J, et al. (2010) MicroRNA-1 and -499 regulate differentiation and proliferation in human-derived cardiomyocyte progenitor cells. Arterioscler Thromb Vasc Biol 30: 859-868.

150. Binah O, Dolnikov K, Sadan O, Shilkrut M, Zeevi-Levin N, et al. (2007) Functional and developmental properties of human embryonic stem cellsderived cardiomyocytes. J Electrocardiol 40: S192-196.
151. Lundy SD, Zhu WZ, Regnier M, Laflamme MA (2013) Structural and Functional Maturation of Cardiomyocytes Derived from Human Pluripotent Stem Cells. Stem Cells Dev.

152. Tiburcy M, Didié M, Boy O, Christalla P, Döker S, et al. (2011) Termina differentiation, advanced organotypic maturation, and modeling of hypertrophic growth in engineered heart tissue. Circ Res 109: 1105-1114.

153. Nistri S, Pini A, Sassoli C, Squecco R, Francini F, et al. (2012) Relaxin promotes growth and maturation of mouse neonatal cardiomyocytes in vitro: clues for cardiac regeneration. J Cell Mol Med 16: 507-519.

154. Goodell MA, Brose K, Paradis G, Conner AS, Mulligan RC (1996) Isolation and functional properties of murine hematopoietic stem cells that are replicating in vivo. J Exp Med 183: 1797-1806.

155.Zhou S, Schuetz JD, Bunting KD, Colapietro AM, Sampath J, et al. (2001) The $A B C$ transporter Bcrp1/ABCG2 is expressed in a wide variety of stem cells and is a molecular determinant of the side-population phenotype. Nat Med 7 : 1028-1034.

156. Martin CM, Meeson AP, Robertson SM, Hawke TJ, Richardson JA, et al. (2004) Persistent expression of the ATP-binding cassette transporter, Abcg2, identifies cardiac SP cells in the developing and adult heart. Dev Biol 265 262-275.

57. Liang SX, Tan TY, Gaudry L, Chong B (2010) Differentiation and migration of Sca1+/CD31- cardiac side population cells in a murine myocardial ischemic model. Int J Cardiol 138: 40-49.

158. Pfister O, Mouquet F, Jain M, Summer R, Helmes M, et al. (2005) CD31- but Not CD31+ cardiac side population cells exhibit functional cardiomyogenic differentiation. Circ Res 97: 52-61.

159. Chamuleau SA, Vrijsen KR, Rokosh DG, Tang XL, Piek JJ, et al. (2009) Cell therapy for ischaemic heart disease: focus on the role of resident cardiac stem cells. Neth Heart J 17: 199-207.

160. Emmert MY, Emmert LS, Martens A, Ismail I, Schmidt-Richter I, et al. (2012) Higher frequencies of BCRP+ cardiac resident cells in ischaemic human myocardium. Eur Heart $\mathrm{J}$

161. Oyama T, Nagai T, Wada H, Naito AT, Matsuura K, et al. (2007) Cardiac side population cells have a potential to migrate and differentiate into cardiomyocytes in vitro and in vivo. J Cell Biol 176: 329-341.

162. Mouquet F, Pfister O, Jain M, Oikonomopoulos A, Ngoy S, et al. (2005) Restoration of cardiac progenitor cells after myocardial infarction by selfproliferation and selective homing of bone marrow-derived stem cells. Circ Res 97: 1090-1092.

163. Lyman SD, Jacobsen SE (1998) c-kit ligand and Flt3 ligand: stem/progenitor cell factors with overlapping yet distinct activities. Blood 91: 1101-1134

164. Miyamoto S, Kawaguchi N, Ellison GM, Matsuoka R, Shin'oka T, et al. (2010) Characterization of long-term cultured c-kit+ cardiac stem cells derived from adult rat hearts. Stem Cells Dev 19: 105-116.

165. Tillmanns J, Rota M, Hosoda T, Misao Y, Esposito G, et al. (2008) Formation of large coronary arteries by cardiac progenitor cells. Proc Natl Acad Sci U S A 105: 1668-1673.

166. Choi SH, Jung SY, Suh W, Baek SH, Kwon SM (2013) Establishment of isolation and expansion protocols for human cardiac C-kit-positive progenitor cells for stem cell therapy. Transplant Proc 45: 420-426.

167.van de Rijn M, Heimfeld S, Spangrude GJ, Weissman IL (1989) Mouse hematopoietic stem-cell antigen Sca- 1 is a member of the Ly- 6 antigen family. Proc Natl Acad Sci U S A 86: 4634-4638.

168. Matsuura K, Nagai T, Nishigaki N, Oyama T, Nishi J, et al. (2004) Adult cardiac Sca-1-positive cells differentiate into beating cardiomyocytes. J Biol Chem 279: 11384-11391.

169. Tateishi K, Ashihara E, Takehara N, Nomura T, Honsho S, et al. (2007) Clonally amplified cardiac stem cells are regulated by Sca-1 signaling for efficient cardiovascular regeneration. J Cell Sci 120: 1791-1800.

170. Bailey B, Fransioli J, Gude NA, Alvarez R Jr, Zhang X, et al. (2012) Sca-1 knockout impairs myocardial and cardiac progenitor cell function. Circ Res 111: $750-760$

171. Goumans MJ, de Boer TP, Smits AM, van Laake LW, van Vliet $P$, et al. (2007) TGF-beta1 induces efficient differentiation of human cardiomyocyte progenito cells into functional cardiomyocytes in vitro. Stem Cell Res 1: 138-149. 
172. Laugwitz KL, Moretti A, Lam J, Gruber P, Chen Y, et al. (2005) Postnatal isl1+ cardioblasts enter fully differentiated cardiomyocyte lineages. Nature 433: 647-653.

173. Davis DR, Ruckdeschel Smith R, Marbán E (2010) Human cardiospheres are a source of stem cells with cardiomyogenic potential. Stem Cells 28: 903-904.

174. Messina E, De Angelis L, Frati G, Morrone S, Chimenti S, et al. (2004) Isolation and expansion of adult cardiac stem cells from human and murine heart. Circ Res 95: 911-921.

175. Andersen DC, Andersen P, Schneider M, Jensen HB, Sheikh SP (2009) Murine "cardiospheres" are not a source of stem cells with cardiomyogenic potential. Stem Cells 27: 1571-1581.

176. Lee ST, White AJ, Matsushita S, Malliaras K, Steenbergen C, et al. (2011) Intramyocardial injection of autologous cardiospheres or cardiosphere-derived cells preserves function and minimizes adverse ventricular remodeling in pigs with heart failure post-myocardial infarction. J Am Coll Cardiol 57: 455-465.

177. Urbanek K, Torella D, Sheikh F, De Angelis A, Nurzynska D, et al. (2005) Myocardial regeneration by activation of multipotent cardiac stem cells in ischemic heart failure. Proc Natl Acad Sci U S A 102: 8692-8697.

178. Genead R, Danielsson C, Andersson AB, Corbascio M, Franco-Cereceda $A$, et al. (2010) Islet-1 cells are cardiac progenitors present during the entire lifespan: from the embryonic stage to adulthood. Stem Cells Dev 19: 16011615

179. Tomita Y, Matsumura K, Wakamatsu Y, Matsuzaki Y, Shibuya I, et al. (2005) Cardiac neural crest cells contribute to the dormant multipotent stem cell in the mammalian heart. J Cell Biol 170: 1135-1146.

180. Quaini F, Urbanek K, Beltrami AP, Finato N, Beltrami CA, et al. (2002) Chimerism of the transplanted heart. N Engl J Med 346: 5-15.

181. Fazel S, Cimini M, Chen L, Li S, Angoulvant D, et al. (2006) Cardioprotective c-kit+ cells are from the bone marrow and regulate the myocardial balance of angiogenic cytokines. J Clin Invest 116: 1865-1877.

182. Assmus B, Schachinger V, Teupe C, Britten M, Lehmann R, et al. (2002) Transplantation of Progenitor Cells and Regeneration Enhancement in Acute Myocardial Infarction (TOPCARE-AMI). Circulation 106: 3009-3017.

183. Lunde K, Solheim S, Aakhus S, Arnesen H, Abdelnoor M, et al. (2006) Intracoronary injection of mononuclear bone marrow cells in acute myocardial infarction. N Engl J Med 355: 1199-1209.

184. Schachinger V, Erbs S, Elsasser A, Haberbosch W, Hambrecht R, et al. (2006) Improved clinical outcome after intracoronary administration of bone-marrowderived progenitor cells in acute myocardial infarction: final 1-year results of the REPAIR-AMI trial. Eur Heart J 27: 2775-2783.

185. Janssens S, Dubois C, Bogaert J, Theunissen K, Deroose C, et al. (2006) Autologous bone marrow-derived stem-cell transfer in patients with STsegment elevation myocardial infarction: double-blind, randomised controlled trial. Lancet 367: 113-121.

186. Rubart M, Pasumarthi KB, Nakajima H, Soonpaa MH, Nakajima HO, et al.

Citation: Cyganek L, Chen S, Borchert T, Guan K (2013) Cardiac Progenitor Cells and their Therapeutic Application for Cardiac Repair. J Clin Exp Cardiolog S11: 008. doi:10.4172/2155-9880.S11-008

This article was originally published in a special issue, Cardiac Stem Cells handled by Editor(s). Dr. Rosalinda Madonna, University of Texas Medical School, USA
(2003) Physiological coupling of donor and host cardiomyocytes after cellular transplantation. Circ Res 92: 1217-1224.

187. Kreke M, Smith RR, Marbán L, Marbán E (2012) Cardiospheres and cardiosphere-derived cells as therapeutic agents following myocardial infarction. Expert Rev Cardiovasc Ther 10: 1185-1194.

188.Zhang Y, Wang D, Chen M, Yang B, Zhang F, et al. (2011) Intramyocardial transplantation of undifferentiated rat induced pluripotent stem cells causes tumorigenesis in the heart. PLoS One 6: e19012.

189. Nsair A, Schenke-Layland K, Van Handel B, Evseenko D, Kahn M, et al. (2012) Characterization and therapeutic potential of induced pluripotent stem cell-derived cardiovascular progenitor cells. PLoS One 7: e45603.

190. Mauritz C, Martens A, Rojas SV, Schnick T, Rathert C, et al. (2011) Induced pluripotent stem cell (iPSC)-derived Flk-1 progenitor cells engraft, differentiate, and improve heart function in a mouse model of acute myocardial infarction. Eur Heart J 32: 2634-2641.

191. Carpenter L, Carr C, Yang CT, Stuckey DJ, Clarke K, et al. (2012) Efficient differentiation of human induced pluripotent stem cells generates cardiac cells that provide protection following myocardial infarction in the rat. Stem Cells Dev 21: 977-986.

192. Rubart M, Field LJ (2007) ES cells for troubled hearts. Nat Biotechnol 25 993-994.

193. Laflamme MA, Gold J, Xu C, Hassanipour M, Rosler E, et al. (2005) Formation of human myocardium in the rat heart from human embryonic stem cells. Am J Pathol 167: 663-671.

194.Leor J, Gerecht S, Cohen S, Miller L, Holbova R, et al. (2007) Human embryonic stem cell transplantation to repair the infarcted myocardium. Heart 93: $1278-1284$

195.van Laake LW, Passier R, Monshouwer-Kloots J, Verkleij AJ, Lips DJ, et al. (2007) Human embryonic stem cell-derived cardiomyocytes survive and mature in the mouse heart and transiently improve function after myocardial infarction. Stem Cell Res 1: 9-24.

196. Robey TE, Saiget MK, Reinecke H, Murry CE (2008) Systems approaches to preventing transplanted cell death in cardiac repair. J Mol Cell Cardiol 45 567-581.

197.leda M, Fu JD, Delgado-Olguin P, Vedantham V, Hayashi Y, et al. (2010) Direct reprogramming of fibroblasts into functional cardiomyocytes by defined factors. Cell 142: 375-386

198. Qian L, Huang Y, Spencer Cl, Foley A, Vedantham V, et al. (2012) In vivo reprogramming of murine cardiac fibroblasts into induced cardiomyocytes. Nature 485: 593-598.

199.Song K, Nam YJ, Luo X, Qi X, Tan W, et al. (2012) Heart repair by reprogramming non-myocytes with cardiac transcription factors. Nature 485 599-604.

200. Jayawardena TM, Egemnazarov B, Finch EA, Zhang L, Payne JA, et al (2012) MicroRNA-mediated in vitro and in vivo direct reprogramming of cardiac fibroblasts to cardiomyocytes. Circ Res 110: 1465-1473.

Submit your next manuscript and get advantages of OMICS Group submissions

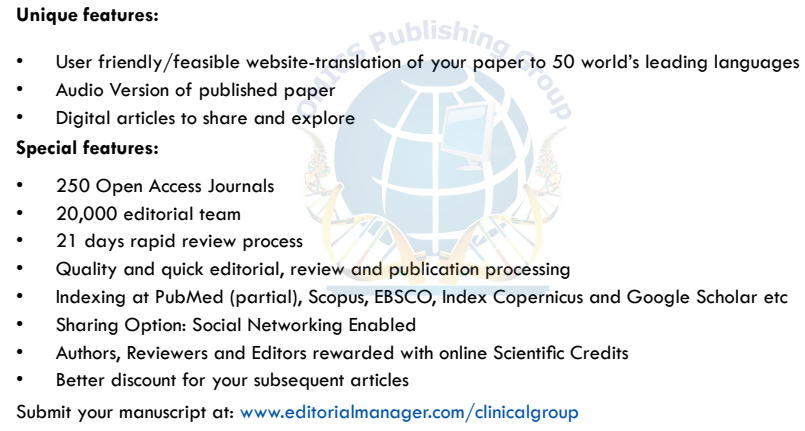

Unique features:

Quality and quick editorial, review and publication processing

Sharing Option: Social Networking Enabled

Better discount for your subsequent articles

Submit your manuscript at: www.editorialmanager.com/clinicalgroup 